\title{
Impact of Tufa Stone Powder as a Partial Replacement of Aggregate on the Mechanical Performance and Durability of Repair Mortar
}

\author{
Omar M. Abdulkareem¹, Abdulrahman Aldaood ${ }^{2}$, Asaad Al-Omari ${ }^{2 *}$, Marwen Bouasker ${ }^{3}$, \\ Amor Ben Fraj ${ }^{4}$, Muzahim Al-Mukhtar ${ }^{3}$ \\ ${ }^{1}$ Environmental Engineering Department, University of Mosul, Al Majmoaa Street, 41002 Mosul, Iraq \\ ${ }^{2}$ Civil Engineering Department, University of Mosul, Al Majmoaa Street, 41002 Mosul, Iraq \\ ${ }^{3}$ University of Orléans-PRISME, 8 rue Léonard de Vinci, 45072 Orléans, France \\ ${ }^{4}$ Cerema, Project-team DIMA, 110 Rue de Paris, BP 214, 77487 Provins Cedex, France \\ * Corresponding author, e-mail: asaad.alomari@uomosul.edu.iq
}

Received: 24 August 2021, Accepted: 27 December 2021, Published online: 20 January 2022

\begin{abstract}
The rehabilitation and reconstruction works are usually performed with a view to conserving these landmarks and maintaining them culturally, architecturally and structurally. From this perspective, the mortars utilized in these repairs must be suitable, physiochemically and mechanically, to the ancient materials used in these buildings. Accordingly, it was proposed to evaluate tufa stone powder, a waste product of one of the most widely found stones in the Loire Valley in France, as an ingredient in repair-work mortar mixtures (M1, M2) through partially replacing the fine aggregate it contains with different amounts of this powder (37\%, 42\%) by weight of mix. Additionally, a third manufacturing mortar (M3) was utilized with both prepared mortars (M1, M2) for comparison with the tufa stone. The mechanical properties (including flexural, compressive and shear strengths, and ultrasonic pulse velocity) and the durability properties (total porosity, thermal dilation and conductivity, capillary absorption, and water and gas permeability) of the three mortars were examined in addition to those of the tufa stone.

The results revealed that the prepared mortar, M2, (having lower binder content and a higher amount of substitution with tufa stone powder) has the lowest mechanical performance in comparison with the other mortars, indicating that this mortar is more supple and loose than the authentic tufa masonry. The thermal and durability properties are comparable to that of the tufa stone existent in ancient monuments. Consequently, the prepared mortar (M2) is the most appropriate mortar, for utilization in repairing old landmarks in the Loire Valley in France.
\end{abstract}

Keywords

repair mortar, tufa stone, historical building, mechanical performance, durability

\section{Introduction}

With the passage of time, the deterioration of building materials is happening either physically, chemically, mechanically or even mineralogically. For many reasons, the elements of ancient structures can be deteriorated. Generally, deterioration occurs and evolves at the interface of the substance with its surroundings or at its interface with another substance. This is governed by the building material itself in terms of several factors: types, features, mass distribution, source and processing techniques, history (former preservation intrusions), and agreement and harmony with other substances. Also, there are other factors relating to the environment that govern the occurrence of deterioration [1]. In the rehabilitation works, the choice of the repair building materials, in terms of its aesthetic appearance, mechanical behavior, and even chemical and mineralogical composition, ought to be appropriate for use with the older substances used in these ancient structures [2, 3]. Accordingly, one of the major requisites in conservation and rehabilitation works is to achieve full compatibility between the ancient stone and restored mortar (i.e., physical, chemical, structural), which should ensure the perfect performance of the repair mortar $[4,5]$.

The origin of the name 'tufa' is the Latin 'tofus', which means spongy stone, relating to its considerable penetrability. Tufa is a widespread French limestone utilized in historical buildings in many areas of France [6]. This stone is 
abundant in Loire Valley, and it has been widely used in the ancient buildings of this area, particularly in their facades, due to its distinguished physical characteristics: its white color and the softness of its particles. As such, this stone has been studied many times previously [7-9]. Generally, tufa stones are carved using machinery equipment in quarries in order to have regular sizes. Thereafter, they are sent to the closest manufactory, and as a result of merging of sand with water through the manufacturing operations, the colloidal waste accumulates in high amounts, creating an environmental load, and getting rid of this waste becomes uneconomic due to growing the cost of this process. Thereby, it was necessary to solve this problem by reusing these wastes, even if in small quantities [10]. Indeed, the techniques of reusing and reclaiming were recently agreed upon in the field of building substances to a large extent. The resemblance between the tufa stone powder and cement in terms of the mineral composition and physical characteristics makes the tufa powder reusable as a partial substitute for cement or aggregate in the cement mortar and concrete used for various applications such as the restoration mortar used in old buildings [11].

The variation of restoration mortars in terms of their ingredients is considerably wide and includes numerous compounds. Lime is the most well-known binder that is used conventionally in repair mortars for old landmarks and monuments in European countries, since it has been used for a very long time [12]. A study of previous research work showed the harmonization between the lime and cement when they were incorporated in the repair mor$\operatorname{tar}[13]$. This reflects positively on the performance of the restoration mortar when used with ancient stone, as this harmonization of physical, chemical and mechanical properties is highly beneficial. Thus, the mixture proportions of the restoration mortar need to be sensible and require high accuracy in terms of the choice of extra components and their properties; for this reason, they should be based on specific experimental investigation. First, the prepared mortar should conserve and improve the visible appearance of the ancient building from an architectural and historical point of view. As building materials, the microstructural profiles of the original and prepared mortars need to have a resemblance. Mechanically, the prepared mortar must neither be stronger than the ancient stone nor feebler than the ancient mortar. The disparity between the components in their strength and stiffness properties weakens the bond between the prepared mortar and the old stone in both the short and long term. In contrast, the prepared mortar is hoped to enhance the durability of the old stone by providing greater resistance against aggressive environments and severe exposures [14, 15].

The goal of this research was to valorise tufa stone powder waste as a partial substitute for fine aggregate in the manufacture of repair mortars. The repair mortar was also evolved to be convenient mortar with the tufa stone being utilized in the old landmark's construction. A different formulation of the suggested repair mortar is designed to examine its suitability experimentally. The experimental investigations include assessment of the mechanical performance of each suggested formulation of the restoration mortar with the aim of identifying the restoration mortar best suited to both ancient mortar and stone. Furthermore, the proposed repair mortars were evaluated regarding the thermal and durability properties that were considered categorical indicators of the suitability of tufa stone powder as a partial constituent in the mix design of the blended repair mortars.

\section{Experimental program}

\subsection{Materials used}

White cement is utilized in the experimental study, and its class is CEM II/B-LL 42.5R CE CP2 NF (Cruas plant). Both its physical and chemical characteristics are displayed in Table 1. The air lime was in accordance to EN 459-1 [16], and it contained about 93\% calcium hydroxide. The tufa stone powder has resulted from the cutting tufa stone as a waste product. Its particle size is in the range of $0.5-80 \mu \mathrm{m}$. The mineralogical and physical characteristics of both the air lime and the tufa stone powder appear in Table 1. Silica sand with a particle size of $20-315 \mu \mathrm{m}$ is utilized in this study as a fine aggregate, and its bulk density is about $1.22 \mathrm{~g} / \mathrm{cm}^{3}$. The particle size distribution of both the tufa stone powder and the silica sand can be observed in Fig. 1.

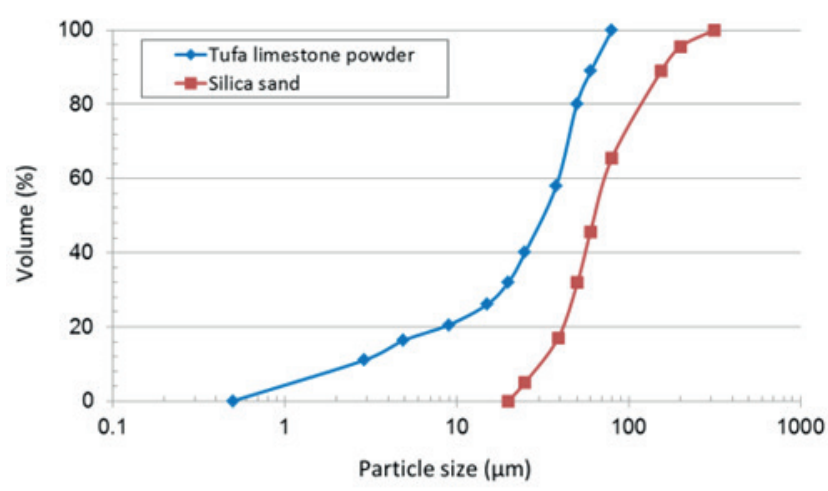

Fig. 1 Particle size distribution of both the tufa stone powder and the silica sand 
Table 1 Mineralogical, chemical and physical characteristics of the materials

\begin{tabular}{|c|c|c|c|c|}
\hline Characteristic & White cement* & Air lime* & Tufa stone powder** & Tufa stone** \\
\hline Mineralogical composition (wt $\%$ ) & $\begin{array}{l}\mathrm{C}_{3} \mathrm{~A} \approx 11 \\
\mathrm{C}_{3} \mathrm{~S} \approx 74 \\
\mathrm{C}_{2} \mathrm{~S} \approx 12\end{array}$ & $\begin{array}{c}\mathrm{Ca}(\mathrm{OH})_{2} \approx 93 \\
\text { Calcite } \approx 4.2\end{array}$ & $\begin{array}{c}\text { Calcite } \approx 50 \\
\text { Opal CT } \approx 30 \\
\text { Quartz } \approx 10 \\
\text { Clay\&Mica } \approx 10\end{array}$ & $\begin{array}{c}\text { Calcite } \approx 50 \\
\text { Opal CT } \approx 30 \\
\text { Quartz } \approx 10 \\
\text { Clay\&Mica } \approx 10\end{array}$ \\
\hline Skeletal density*** $\left(\mathrm{g} / \mathrm{cm}^{3}\right)$ & 3.13 & 2.21 & 2.55 & 2.55 \\
\hline Bulk dry density $\left(\mathrm{g} / \mathrm{cm}^{3}\right)$ & - & 0.38 & 0.85 & 1.31 \\
\hline Blaine surface $\left(\mathrm{cm}^{2} / \mathrm{g}\right)$ & 5300 & 11900 & - & - \\
\hline Compressive strength at 28 days ( $\mathrm{MPa})$ & 56 & - & - & - \\
\hline Porosity (\%) & - & - & - & 48 \\
\hline
\end{tabular}

*Data from the factories; **[6]; ***Skeletal density is the ratio of the mass of solid material to the sum of the volumes of the solid material and closed (or blind) pores within the material (ASTM D3766)

Tap water is utilized for all manufactured mortars. Sika Viscobond is used in the admixture in this work as a bonding agent to enhance the bonding and adhesiveness between the mortar and the old tufa stone. Beside these constituents, the raw tufa stone was quarried at Saint-Cyr-en-Bourg in the region of Maine-et-Loire in France. The major features of this stone are that it is a white stone, it is quite light (bulk dry density of $1.31 \mathrm{~g} / \mathrm{cm}^{3}$ ), and it is an 'easy to sculpt' when used in ancient buildings for repair and rehabilitation purposes. Mineralogically, tufa stone essentially consists of both calcite and silica, as shown in Table 1. As well as this, the stone porosity was around $48 \%$ with an extra broad range of pore size distribution of (0.003-20) $\mu \mathrm{m}$; for these reasons, the stone has a very limited compressive strength of $10 \mathrm{MPa}$.

\subsection{Preparation of mortars}

Two mortars (M1, M2) were prepared in this study. Each mortar was composed of different proportions of white cement, air lime, tufa stone powder and silica sand, as shown in Table 2. Two binder amounts have been incorporated in the two prepared mortars $(25 \%, 15 \%)$, and the proportion of each binder was kept constant for each prepared mortar (one-third of white cement with two-thirds of lime). The silica sand was partially replaced by tufa stone powder in two levels $(37 \%, 42 \%)$ as a weight percentage of the total mix proportion, and thus, the amounts of these two components were variable in each prepared mortar, as can be observed in Table 2 . The value of water/solid was 0.4 for

Table 2 Mix proportioning of the prepared mortars

\begin{tabular}{lccc}
\hline $\begin{array}{l}\text { Mixture } \\
\text { designation }\end{array}$ & Binder (wt $\%)$ & $\begin{array}{c}\text { Tufa stonepowder } \\
(\mathrm{wt} \%)\end{array}$ & $\begin{array}{c}\text { Silica } \\
\text { sand (wt } \%)\end{array}$ \\
\hline M1 & $\begin{array}{c}25 \%(2 / 3 \text { Lime }+ \\
1 / 3 \text { White cement) }\end{array}$ & $37 \%$ & $38 \%$ \\
& $\begin{array}{l}15 \%(2 / 3 \text { Lime }+ \\
\text { M2 }\end{array}$ & $42 \%$ & $43 \%$ \\
\hline
\end{tabular}

both prepared mortars. When the preparation of the mortars was completed, the specimens were kept at a temperature of $20 \pm 2{ }^{\circ} \mathrm{C}$ and a relative humidity of $75 \%$. The skeletal and bulk densities of mortar M1 were $1.96 \mathrm{~g} / \mathrm{cm}^{3}$ and $1.37 \mathrm{~g} / \mathrm{cm}^{3}$ while the skeletal and bulk densities of mortar $\mathrm{M} 2$ were $1.81 \mathrm{~g} / \mathrm{cm}^{3}$ and $1.31 \mathrm{~g} / \mathrm{cm}^{3}$ respectively.

Beside the two prepared mortars, the restoration mortar M3 (LEGASTON R) marketed by the company Véga Industries was chosen for use. This mortar is based on lime and limestone sand and distinctive admixtures and makes it possible to repair and reconstitute soft stones that have been broken up and chipped. The mix proportion of this manufacturing mortar was not available due to it being an innovative output. The skeletal and bulk densities were $2.17 \mathrm{~g} / \mathrm{cm}^{3}$ and $1.62 \mathrm{~g} / \mathrm{cm}^{3}$, respectively.

\subsection{Testing methods}

\subsubsection{Total porosity and pore size distribution}

The total porosity (ØТ) is one of the main physical properties of a porous material. This property was determined by following the hydrostatic weighing method based on Archimedes's principle, in accordance with the procedure described by Reunion Internationale des Laboratories d'Essais et de Recherches sur les Materiaux et les Constructions (RILEM) [17]. Twenty specimens were used to measure the total porosity of the mortar and tufa stone specimens (Table 3). The mean value of total porosity was estimated for each five specimens. The pore diameter distribution was measured through a mercury intrusion porosimetry (MIP) test. The utilized device was an Autopore IV 9520 micro-porosimeter that can create pressures from around $2.76 \mathrm{kPa}$ up to $414 \mathrm{MPa}$ and permits the determination of pore diameter sizes in the range of $0.003-450 \mu \mathrm{m}$. For each mortar and stone, three specimens were tested and the mean value was estimated. 
Table 3 Specimens tested in the experimental program

\begin{tabular}{lcc}
\hline Property & Specimen type & $\begin{array}{c}\text { Specimen } \\
\text { dimensions }(\mathrm{cm})\end{array}$ \\
\hline Total porosity & $\begin{array}{c}\text { Small pieces with } \\
\text { irregular shapes }\end{array}$ & $5 \mathrm{~cm}^{3}-10 \mathrm{~cm}^{3}$ \\
Flexural strength & Prism & $4 \mathrm{~cm} \times 4 \mathrm{~cm} \times 16 \mathrm{~cm}$ \\
Compressive strength & Cylindrical & $4 \mathrm{~cm}(\mathrm{D}) \times 4 \mathrm{~cm}(\mathrm{H})$ \\
Shear strength & Cylindrical & $4 \mathrm{~cm}(\mathrm{D}) \times 4 \mathrm{~cm}(\mathrm{H})$ \\
Ultrasonic pulse velocity & Cylindrical & $4 \mathrm{~cm}(\mathrm{D}) \times 8 \mathrm{~cm}(\mathrm{H})$ \\
$\begin{array}{l}\text { Thermal conductivity } \\
\text { and dilation }\end{array}$ & Cylindrical & $0.5 \mathrm{~cm}(\mathrm{D}) \times 2 \mathrm{~cm}(\mathrm{H})$ \\
$\begin{array}{l}\text { Capillary water } \\
\text { absorption }\end{array}$ & Cylindrical & $5 \mathrm{~cm}(\mathrm{D}) \times 5 \mathrm{~cm}(\mathrm{H})$ \\
Water permeability & Cylindrical & $4 \mathrm{~cm}(\mathrm{D}) \times 4 \mathrm{~cm}(\mathrm{H})$ \\
Gas permeability & Cylindrical & $5 \mathrm{~cm}(\mathrm{D}) \times 5 \mathrm{~cm}(\mathrm{H})$ \\
\hline
\end{tabular}

\subsubsection{Flexural and compressive strengths}

Both flexural and compressive strengths were measured using an Instron 4485 press machine with a capacity of $250 \mathrm{kN}$ and a loading rate of $0.2 \mathrm{~mm} / \mathrm{min}$. The type of flexure is 3-points flexure bending test. Twelve specimens were tested at 14, 28 and 60 days (Table 3). The testing method was carried out in accordance with the standard EN 1015-11 [18]. The average value of flexural strength was reported for each three readings. For the compressive strength, the standard NF-P94-420 [19] was performed on twenty cylindrical specimens with diameters of $4 \mathrm{~cm}$ and heights of $4 \mathrm{~cm}$ that were utilized for mortars and tufa stone and tested at 14, 28 and 60 days. The average value of compressive strength was reported for each five specimens.

\subsubsection{Shear strength at the interface}

Saturated cylindrical specimens were utilized and tested at 14, 28 and 60 days (Table 3). Each specimen contained $2 \mathrm{~cm}$ of the adhesive mortar with $2 \mathrm{~cm}$ of tufa stone in the assembling state as shown in Fig. 2. The direct shear strength test (typically used in geotechnical tests) was utilized to examine shear strength according to ASTM D3080-11 [20]. The specimen was put in between the box's bisections, which move proportionally to one another. At a steady loading rate of $0.5 \mathrm{~mm} / \mathrm{min}$, the bottom bisection was moved while the top bisection was

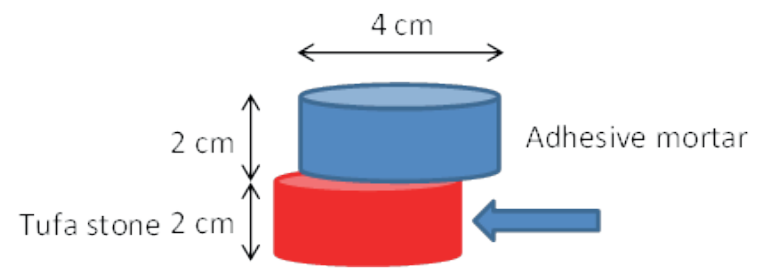

Fig. 2 Schematic drawing of shear test specimens stationary, and they were linked with a loading circle for the purpose of determining the shear level loads (as shown in Fig. 3). The horizontal forces produce a good representative stress on the shear plane of the specimen to describe the friction state at the interface of the mortar and stone. Twenty specimens were tested, and the mean value of the shear strength for each five specimens was reported.

\subsubsection{Ultrasonic pulse velocity}

Ultrasonic pulse velocity was determined in accordance with the standard NF-P94-411 [21] for twenty specimens (Table 3). A Pundit apparatus, with a small wave frequency of $82 \mathrm{kHz}$, was utilized for measuring the wave passage velocity. The ultrasonic pulse velocity was examined for specimens at 14, 28 and 60 days. Each value of the ultrasonic pulse velocity was the mean of five readings.

\subsubsection{Thermal conductivity and dilation}

Thermal conductivity was achieved through utilizing the traditional hot wire mechanism in accordance with the standard ASTM D5930-97 [22]. Twenty specimens were oven-dried at $60^{\circ} \mathrm{C}$ during $48 \mathrm{~h}$, wrapped into plastic films, and then tested at 28 days (Table 3 ). An apparatus of FP2C was utilized for immediate determination of the thermal conductivity and provided a hot wire plumb line between two specimens with an identical geometry. The thermal conductivity is specified by taking into consideration that the temperature development is a function of the time logarithm. The hot wire, nickel type, is selected to somewhat increase the temperature of the specimens after passing of an electrical current. The specimens are conducted as an unlimited medium through the test [23]. The mean value of the thermal conductivity coefficient for each of the five specimens was reported.

Thermal dilation was fulfilled using an LINSEIS, TMA PT1000 for twenty specimens (Table 3) [24]. The thermal dilation can be determined through subjection of the specimen to various temperatures of 20, 40 and $60{ }^{\circ} \mathrm{C}$. Each specimen was preserved for a whole day prior to the deformity determination. The specimens were plastic-wrapped

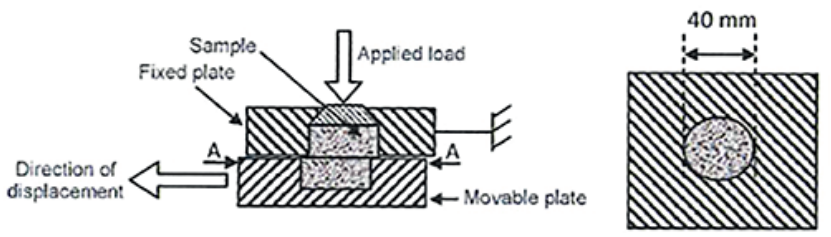

Fig. 3 Shear strength test (Left: Overview of the shear test, Right: Section A-A) 
for the purpose of averting dryness and tested at 28 days. The average value of coefficient of thermal dilation was estimated for each five specimens.

\subsubsection{Capillary water absorption}

The water rising in a perpendicular cylindrical pored pipe is estimated by the Washburn model, which ignores gravitational impact. Two different imbibition factors ( $A$ and $B$ ) can be obtained from this test. These two factors were compatible with the inclination of the curve of the mass uptake $(M)$ and the height of the anterior capillary pursuant $(h)$ to the square root of the time spent [6]. In fact, the capillary water absorption test is further specific to describe the imbibition kinetics with time $(h$ and $M)$ and clearly denotes the effect of porous medium features on the activity of the imbibition. Finally, the capillary porosity $\left(N_{c}\right)$ can be estimated from this test using the relationship: $A=\rho_{\text {water }} B N_{c}$.

In accordance with the standard EN-1925 [25], twelve formerly exsiccated specimens were tested (Table 3 ). The mean value of capillary absorption coefficient was estimated for three readings of mortar and stone.

\subsubsection{Water and gas permeability}

The water permeability test was considered a good way to gather more information about the water transfer properties of the studied specimens. Twenty specimens were examined in this test (Table 3). The vacuum saturation method was followed to prepare the specimens in a fully saturated condition. The test was performed by following the approach described by El-Dieb and Hooton [26], and a high-pressure triaxial cell was used to measure the water permeability in the range $10-12 \mathrm{~m} / \mathrm{s}$ to $10-16 \mathrm{~m} / \mathrm{s}$. An automatic hydraulic pressure system was employed to obtain constant head pressure. Prior to the test, the steady-state condition was checked so that the Darcy law was applicable. During the test, entrapped air bubbles were avoided and proper saturation of the specimens was maintained by adopting a bottom-up water flow direction. Furthermore, the confining pressure was subjected to the tested specimens by another automatic hydraulic pressure system, and the one-directional flow of water was achieved by setting up the confining pressure being slightly higher than the applied head pressure. The mean value of coefficient of water permeability was estimated for each five readings. Twenty specimens used for the gas permeability test were obtained by making a static compaction of the mortar in a stainless steel cylindrical mold, with the specimens (Table 3).
Measurements of gas permeability were achieved at the curing age in accordance with the test procedures depended by Saiyouri et al. [27] and Aldaood et al. [28].

The average value of coefficient of gas permeability was estimated for each five readings. Table 3 shows aforementioned properties in addition to their specimens types and dimensions.

\section{Results and discussions}

\subsection{Pore size distribution and total porosities}

Fig. 4 exhibits the curves of the pore size distribution for all the mortars and the tufa stone obtained through the MIP test. All the porosities measured are presented in Table 4. Furthermore, the results of MIP test are depicted in Fig. 4. As shown in Fig. 4, the pore diameters of $0.6 \mu \mathrm{m}$ and $1.6 \mu \mathrm{m}$ are most suitable for the manufactured mortar M3, which denotes that this mortar has the finest porous skeleton with these two peaks. For the prepared mortar M1, two peaks of the pore diameter are noticed in Fig. 4 $2.5 \mu \mathrm{m}$ and $1.6 \mu \mathrm{m}$ - indicating that this mortar has a little coarseness to its pore structure in comparison with the manufactured mortar M3.

In contrast, the prepared mortar M2 has a mean pore diameter of $2.5 \mu \mathrm{m}$, as shown in Fig. 4. However, all the diameters of pores for the three mortars are considerably less than that of tufa stone, which has a peak of $8.4 \mu \mathrm{m}$. Likewise, these results agree with the values of the total porosities in Table 4.

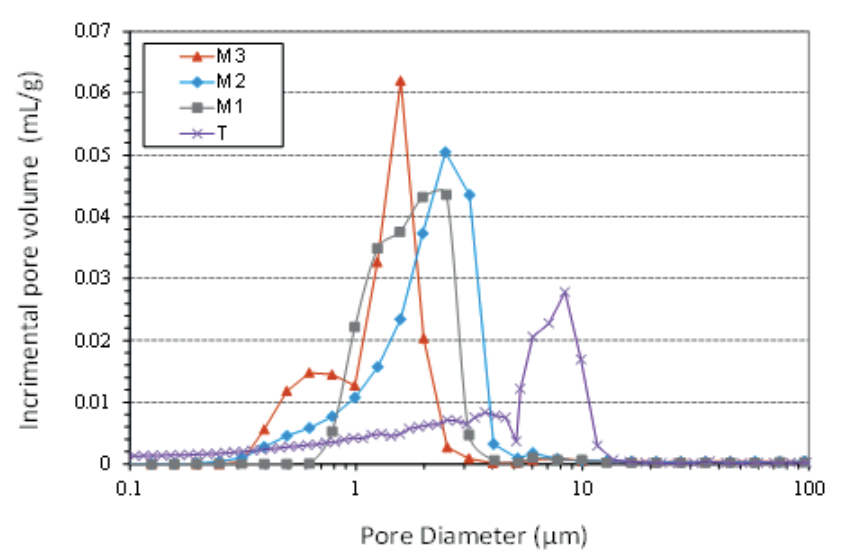

Fig. 4 Pore size distribution of the mortars and tufa stone

Table 4 Total porosity of the mortars and tufa stone

\begin{tabular}{lc}
\hline Material & Total porosity (\%) \\
\hline M1 & $43.28 \pm 1.27$ \\
M2 & $47.16 \pm 0.08$ \\
M3 & $29.45 \pm 0.08$ \\
Tufa stone & $48.12 \pm 0.58$ \\
\hline
\end{tabular}


Indeed, the binder content appears to be highly impactful on the pore structure of the mortar, as in the prepared mortar M2 containing lower binder content (15\%), which is more porous compared with mortar M1, which has about 25\% binder content. Moreover, the aggregate amount incorporated impacts the microstructure of the mortar, and the usage of a $42 \%$ substitution of the total aggregate amount in mortar M2 resulted in further porosity, indicating that an increased aggregate substitution rate attains a greater total porosity (47\%) [29]. In any case, the mortar seems porous to a smaller extent and has a further homogeneity when the lime rate in the paste of the mortar (i.e., binder) increases, and the pore diameter distribution alters with an increment in lime rate and shares in diminutive pores [6]. It is evident that the prepared mortars M1 and M2 did not have similar degrees of hydration and carbonation reactions, due to the variation of both the binder amount and the partial substitution with tufa stone powder. Because of the synthetic resemblance between the binder and aggregate particles, in addition to the effectiveness of the limestone particles in the reaction of carbonation, the aggregate particles play a nucleating role for the newly configured calcite crystal. Moreover, limestone supplies a convenient surface for the nucleation and evolution of $\mathrm{C}-\mathrm{S}-\mathrm{H}$ gel at early age, which boosts the hydration process. Crystals of calcite appear to be miniature crystals of portlandite, and link with each other for circumambient particles of aggregates, leading to smaller pores, restricting the total porosity and enhancing the mechanical performance. Accordingly, the lower content of lime incorporated into the binder in mortar $\left(\mathrm{M}_{2}\right)$ exhibits an ineffectual carbonation reaction through a lowered packing density and fewer nucleation centers that support both the hydration and carbonation reactions and the crystallized calcite formation. Therefore, the pore structure became less compacted and more porous, with a total porosity of $47 \%$ and a mean pore diameter of $2.5 \mu \mathrm{m}$ [30]. The lower content of lime incorporated into the binder in mortar M2 exhibits an ineffectual carbonation reaction through a lowered packing density and fewer nucleation centers that support both the hydration and carbonation reactions and the crystallized calcite formation, and therefore, the pore structure became less compacted and more porous, with a total porosity of $47 \%$ and a mean pore diameter of $2.5 \mu \mathrm{m}$, as observed in Table 4 and Fig. 4, respectively. The pore structure characteristics of the mortar are essential to ensure compatibility with the ancient masonry. The mortar M2 has less-compacted pore structure and porosity closer to that of tufa stone, and therefore the compatibility between this mortar and the stone reduces. When the mortar with a low proportion of fine pores was subjected to the pressure of crystallization, it did have the potential to deteriorate the stone [15].

\subsection{Mechanical properties}

\subsubsection{Flexural and compressive and strengths}

The measurements of flexural and compressive strength for the three mortars and tufa stone at 14, 28 and 60 days can be seen in Figs. 5 and 6, respectively.

The results shown indicate lower strengths for the three mortars in comparison with the tufa stone. M2 had the lowest flexural strength and the lowest compressive strength at all ages (14, 28 and 60 days) compared to the other mortars (M1, M3). The limited properties in terms of strength, toughness and deformity of M2 may be regarded as a recommendable in the repair and rehabilitation of ancient landmarks, considering that M2 could possibly be used as a protective layer of the old tufa stone in landmarks so that the phenomenon of decay, regardless of its cause, can occur in this layer (i.e. the prepared mortar, M2) without causing any

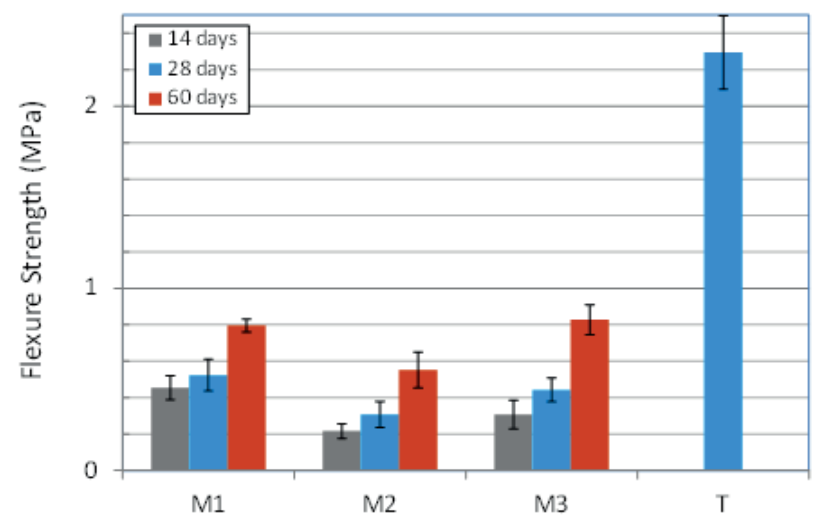

Fig. 5 Flexure strength of the mortars and tufa stone at 14, 28 and 60 days

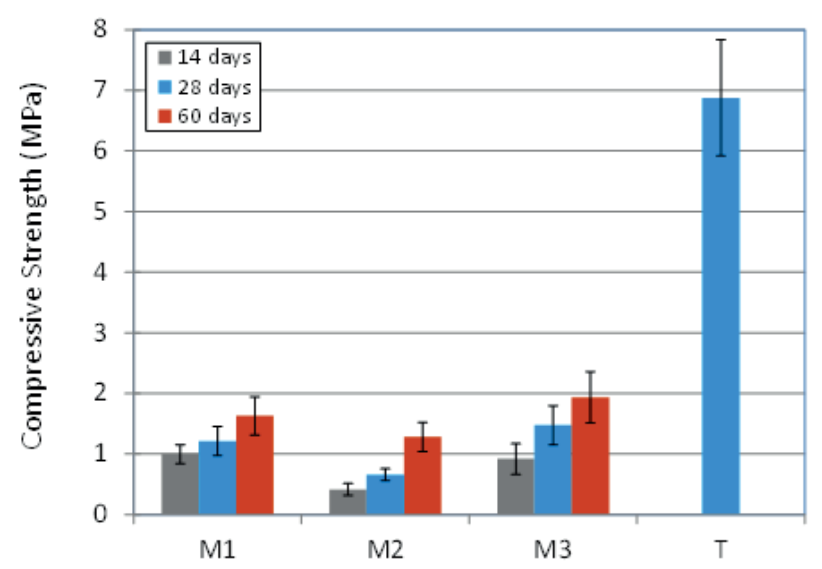

Fig. 6 Compressive strength of the mortars and tufa stone at 14, 28 and 60 days 
deterioration of the old stone, meaning it will remain intact [31]. As mentioned before, the lower the binder amount as in the mortar M2 is, the lower the hydration rate is for the hydraulic elements because of the restricted pozzolanic reactions between the air lime and the silica components in the mortar accompanied with the portlandite increase through the reaction, and thus, the amount of hydrated products was limited. Likewise, both the solubility and reactivity of the silica components were reduced on account of the lower quantity of lime in the mortar, leading to a reduced $\mathrm{pH}$ value. The lower content of the lime incorporated in the binder of M2 exhibits an ineffectual carbonation reaction [14]. The limited calcite found in the limestone powder supplies, in turn, insufficient nucleating agents to develop the crystals through carbonation of the portlandite, leading to enhance the total porosity and create a lower dense pore network in the nucleus of mortar, as shown in both Table 4 and Fig. 4, and hence, the strength was diminished.

Contrary to the prepared mortar M1 with a greater binder content of $25 \%$, and reduced substitution level of tufa limestone powder of $37 \%$, the packing density was increased, and more nucleation agents supported both the hydration and carbonation reactions and crystalline development. The open porosity was reduced with the appearance of two peaks in the pore diameter distribution of 2.5 and $1.6 \mu \mathrm{m}$, as observed in Table 4 and Fig. 4, and consequently, the strength increased [32]. M2 exhibits less flexural and compressive strength than the tufa. This advantage is convenient for the intended usage of the restoration mortar to bind the ancient mortars and the masonry units.

\subsubsection{Shear at the interface}

Fig. 7 shows the results of the ultimate shear strength of the mortars and tufa stone at the ages (14, 28 and 60) days, while Fig. 8 displays the shear strengths of the mortarstone interface.

It is revealed in Fig. 7 that the shear strengths of the mortars (M1, M2 and M3) converge together, but they are dissimilar to the tufa stone. Moreover, as observed in Fig. 8, the results of the shear strength at the interface of each mortar-tufa stone exhibited a perfect adhesiveness. Generally, the adhesiveness exhibited at the interface of mortar-tufa stone. So the perfect adhesiveness is for the mortar having the higher shear strength at the interface (M3). The adhesion ability between the mortar and the stone relies on the mineral and chemical properties. In other words, it relies on the type of the contact area between the stone and the mortar (i.e., transition zone).

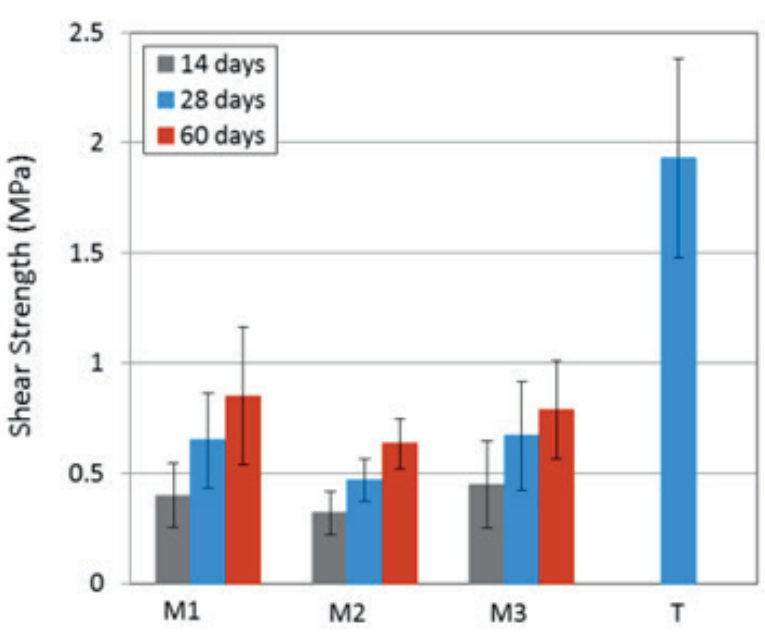

Fig. 7 Shear strength of the mortars and tufa stone at 14, 28 and 60 days

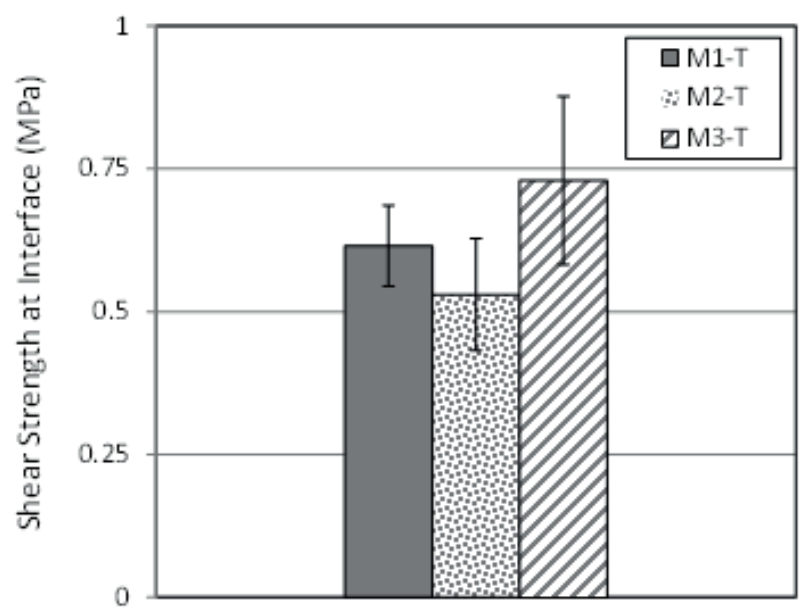

Fig. 8 Shear interface of mortar-stone

Likewise, the procedure of strength in the shear state was affected by this parameter [33]. Both the fissures and failures begin with a further weak element, whether it is in the masonry itself, in the mortar itself or at the interface between them. The restricted shear strength of the repair mortar M2 was less than its strength at the interface with the stone, and the rupture occurred in the weakest element, the mortar M2. Thus, that ensures its suitability and also that any failure in the mortar itself, without extending to the interface with the tufa stone, does not reach the tufa itself.

\subsubsection{Ultrasonic pulse velocity}

Fig. 9 shows the results of the ultrasonic pulse velocity of the used mortars (M1, M2, M3) and the tufa stone.

As stated before, both the mineral structure and porosity (i.e., total porosity and pore size distribution) of a mortar may influence its mechanical properties including strength, mode of deformation and ultrasonic pulse velocity. The 


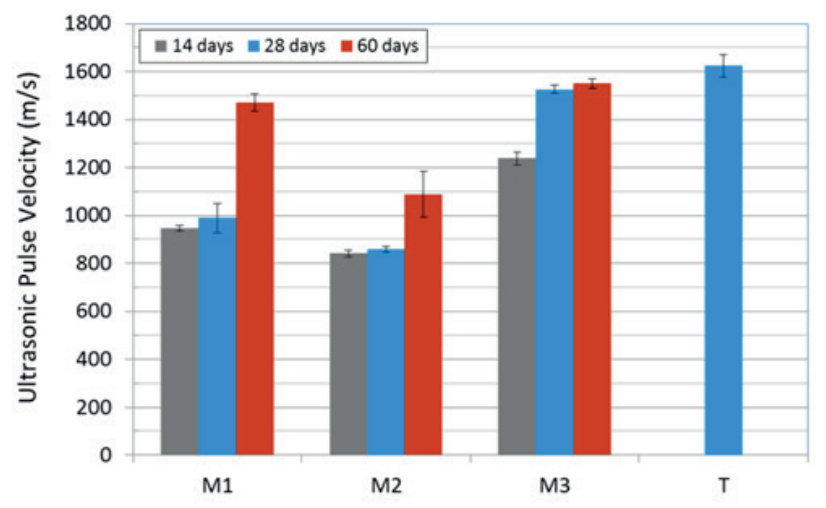

Fig. 9 Ultrasonic pulse velocity of the mortars and tufa stone at 14, 28 and 60 days

ultrasonic pulse velocity is greatly impacted by the porosity. When the rate of wave transition reduces, this indicates that the mortar is more porous and has less strength. Hence, the more belated and weakened waves are recorded in the more porous mortar M2 as observed in Fig. 9 [6, 34].

\subsection{Durability properties}

\subsubsection{Thermal conductivity and dilatation}

Fig. 10 presents the results for coefficients of thermal conductivity and dilation for the mortars and tufa stone. As shown, the coefficients of thermal dilation for both M2 and the tufa stone were alike, while the coefficients of M1 and M3 were not similar with that of the tufa stone. Relating to the thermal conductivity, there is a similarity in coefficients of thermal conductivity for both the mortars (M1 and M2) with that of tufa stone conductivity coefficient. The closed thermal behavior of the prepared mortar M2 and the tufa stone emphasizes the suitability of the mortar M2 for use for the preservation of the ancient buildings and historic landmarks. Usually, there are several elements that could affect the thermal conductivity of mortar, such as binder amount and both amount and type of aggregate [35].

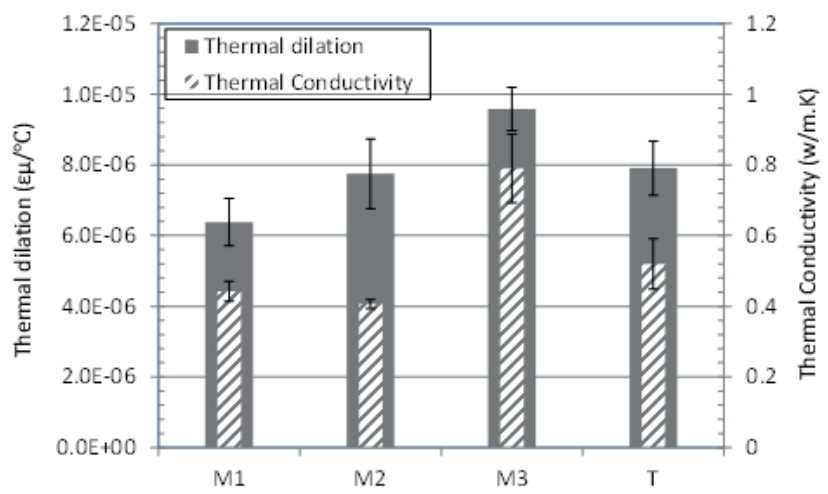

Fig. 10 Thermal dilation and thermal conductivity coefficients of the mortars and tufa stone
Concerning mortar M2, the porosity and pore network of the mortar also have an influence on its thermal conductivity and dilation. The heat transmission is reduced for the porous mortar, and its thermal dilation is changed. Furthermore, when the diameter of the pores is larger, the heat conduction probably increases by dint of the formation of heat bridges [35].

In comparison with the repair mortar M1, M2 attained a larger thermal dilation coefficient, as exhibited in Fig. 10. Nonetheless, the value of this coefficient was close to that of the tufa stone's dilation coefficient, which confirms the compatibility of the repair mortar M2 with the tufa stone.

This can be attributed to the fact that this convergent thermal dilation coefficient between both components (i.e., the repair mortar M2 with the tufa stone) is an efficacious way to reduce the inner stresses generated from of atmospheric changes. Furthermore, this similarity in thermal dilation supports the homogeneity of behavior of the mortar and tufa stone over a prolonged period under atmospheric changes [36].

\subsubsection{Capillary absorption}

The amount of water transmission by means of imbibition through the capillary action in the repair mortars and tufa stone is assessed using the coefficient of capillary absorption. Fig. 11 shows the development of capillary front height versus the square root function of the time for the various mortars and the tufa stone. Fig. 12 shows the weight increase from the capillary water (i.e., water absorbed through imbibition) versus the square root function of the time for both mortars and tufa at different curing times. Furthermore, the evolution of the coefficients of imbibition, including mass coefficient (A) and visual coefficient (B) for the mortars and stone, appears in Table 5. The heights of the absorbed water of the prepared mortar M2 and the tufa stone are alike. Conversely, the prepared

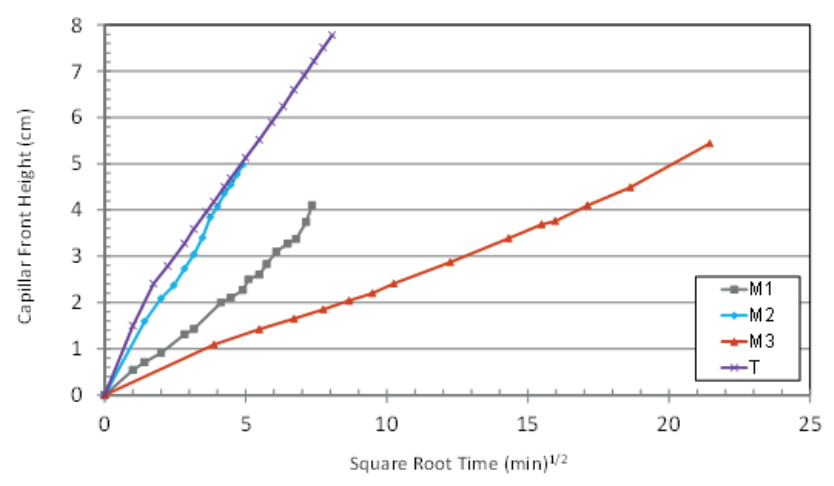

Fig. 11 Imbibition test for mortars and tufa stone 


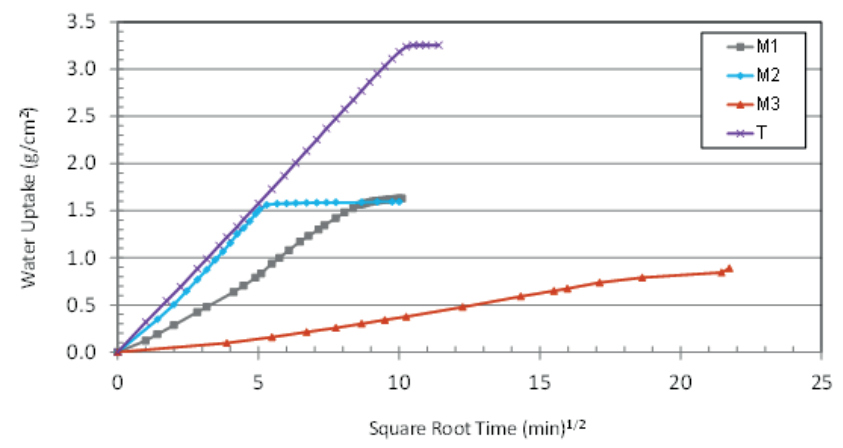

Fig. 12 Weight of absorbed water in mortars and tufa stone

Table 5 Results of capillary water absorption tests for mortars and tufa stone

\begin{tabular}{lcc}
\hline Material & $\begin{array}{c}\text { Mass coefficient (A) } \\
\left(\mathrm{g} / \mathrm{cm}^{2} / \mathrm{min}^{1 / 2}\right)\end{array}$ & $\begin{array}{c}\text { Visual coefficient (B) } \\
\left(\mathrm{g} / \mathrm{cm}^{2} / \mathrm{min}^{1 / 2}\right)\end{array}$ \\
\hline M1 & $0.192 \pm 0.041$ & $0.523 \pm 0.054$ \\
M2 & $0.309 \pm 0.074$ & $1.010 \pm 0.154$ \\
M3 & $0.043 \pm 0.015$ & $0.241 \pm 0.042$ \\
Tufa stone & $0.320 \pm 0.098$ & $0.901 \pm 0.087$ \\
\hline
\end{tabular}

mortar M1 and manufactured mortar M3 have dissimilar absorbed water heights in comparison with that of tufa stone, as shown in Fig. 11. The amounts of weight growth of absorbed water in addition to the mass and visual coefficients for both M2 and tufa stone were also convergent as appeared in Fig. 12 and Table 5 consecutively.

The results show that the main cause of the changes in water transport by capillarity action was the mix proportion of the repair mortar in terms of the amount of binder and the replacement level of the tufa stone powder [34, 37].

For the repair mortar M2, the passage of water is more restricted through this repair mortar compared to that which might have been transmitted through the tufa stone pores. The greater water absorption capacity and larger internal porosity of the limestone particles can be attributed to their calcic characteristics in terms of the existence of clay minerals that could impact the content of the water of the repair mortar.

From the perspective of compatibility, the water absorption by means of capillary action for the restoration mortar M2 and the tufa stone were similar. Any dissimilarity between the repair mortar and the tufa stone in terms of the capillary imbibition possibly enables the soluble salts to be lost through the interfacial zone between them and crystallize, which accelerates the deterioration of ancient stone.

\subsubsection{Water and gas permeability}

Fig. 13 shows the coefficients of water permeability of the mortars and tufa stone at 14, 28 and 60 days, while Fig. 14 exhibits the coefficients of gas permeability of the mortars

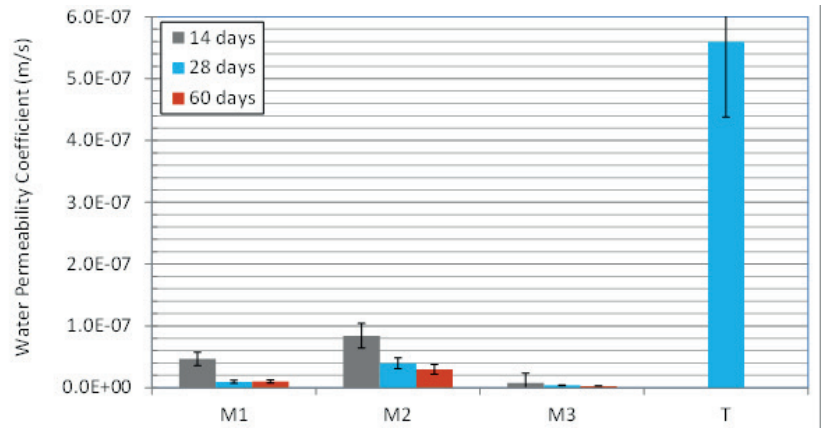

Fig. 13 Water permeability coefficients of mortars and tufa stone at 14, 28 and 60 days

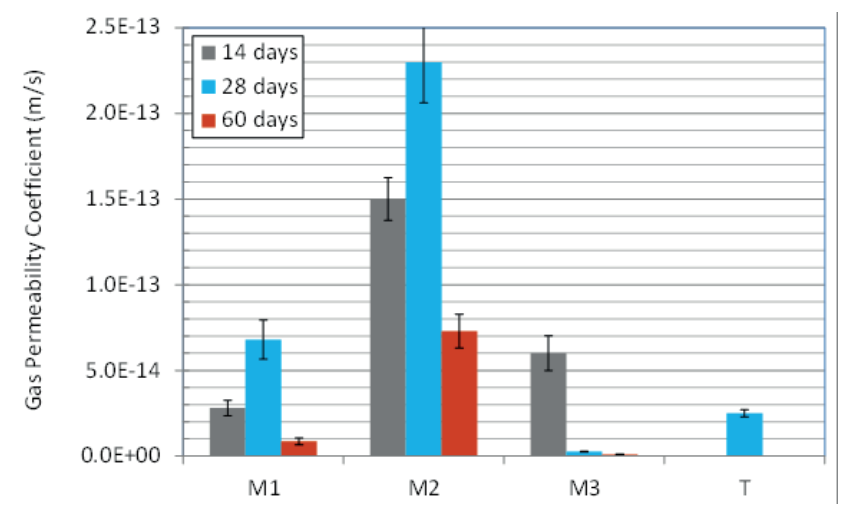

Fig. 14 Gas permeability coefficients of mortars and tufa stone at 14, 28 and 60 days

and tufa stone at 14, 28 and 60 days. As depicted in these figures, the prepared mortar M2 exhibited larger coefficients of water and gas permeability at all ages compared to the prepared mortar M1 and the manufactured mortar M3. The gas permeability coefficient of mortar M2 was also greater than that of tufa stone, as shown in Fig. 14. This in turn confirms the aforementioned statement that it is the most appropriate mortar for use with ancient stone due to its composition. When the repair mortar shows greater permeability by water and gasses than the ancient masonry, the transmission of water decreases in the pore skeleton of the stone due to the evaporation of water taking place rapidly through the pores of the mortar. As shown in Table 4, the large and convergent total porosities of M2 and the tufa denote higher permeability, which can allow a rapid level of drying and have a lower tendency to fissure and thereby impact durability [15]. The incorporation of aggregate increases the porosity and makes the transmission of water and gas easier, whereas the porosity of the binder matrix lowers with an increased binder amount [38]. The utilization of the mortar with a larger lime content than cement allows greater permeability to fluids of various kinds because of the generation of a further open-pore skeleton, which is a key factor for repair mortars [39], and which markedly impacts water transmission [14]. 
As is commonly known, the presence of water contributes significantly to masonry decay in various forms. Thus, the mortar's potential for water transmission must be the same or perhaps greater than that of the tufa stone. This means that it will release the water in the tufa faster in comparison to a mortar with a smaller capacity for water transmission than the tufa stone [40].

\section{Conclusions}

This study aimed to investigate the valorization of tufa stone powder as a material in the partial replacement of fine aggregate in the production of mortar to be used for repairing the tufa stone/masonry in the ancient buildings of the Loire Valley in France. It can be deduced that mortar M2 with a lower binder amount (15\%) and a greater rate of fine aggregate substitution by tufa powder (42\%) was the most compatible and suitable mortar for old monuments built from tufa stone. The reasons for this can be summarized as follows:

- The mortar M2 is the most porous mortar that has one peak of pore diameter, which is smaller than that of the tufa stone. Nonetheless, the total porosities of them are similar. Thanks to the high porosity of this mortar, its pores provide a space for salts to crystallize under intensified pressure.

- The lower flexural and compressive strengths of the mortar M2 make it a good conservation material. This means the chance of cracks appearing is reduced and deterioration can be borne in the mortar media without any impact on the ancient stone.

- The low shear strength at the interface of this mortar and the tufa stone is preferable for the conservation of the old landmarks as it guarantees an appropriate adhesion between the mortar and the masonry, and it also reflects the ability of this mortar to resist shear stresses and other dynamic loads.

- The low ultrasonic pulse velocity of the mortar M2 denotes low adhesive strength in the interfacial zone between the mortar and the stone, an inner linkage

\section{References}

[1] Al-Omari, A., Brunetaud, X., Beck, K., Al-Mukhtar, M. "Climatic conditions and limestone decay in Al-Namrud monuments, Iraq: Review and discussion", In: 2012 First National Conference for Engineering Sciences (FNCES), IEEE, Baghdad, Iraq, 2012, pp. 1-7. https://doi.org/10.1109/NCES.2012.6740455

[2] Kósa, Z., Török, Á. "Characterization of Historic Binders and Stones of a Ruined Medieval Church (Hungary)", Periodica Polytechnica Civil Engineering, 64(2), pp. 597-604, 2020.

https://oi.org/10.3311/PPci.15599 of the different mortar components, again, reduced decay in the ancient stone.

- The mortar M2 has similar thermal behavior to the tufa stone, which means that this mortar is more capable to reduce the stresses that arise at the contact area as a result of changes in climate conditions.

- The similar capillary absorption behavior for this mortar and the tufa stone indicate that the water movement in this mortar is limited, and thus the penetration of the soluble salts through the contact area between the mortar and stone will be restricted.

- The mortar M2 exhibited closer permeability coefficients of water and gases to that of the tufa stone at different curing times. This mortar could considerably reduce the transmission of both water and gas in the tufa's pore skeleton on account of the fast evaporation of these substances through the mortar's pores.

- Furthermore, based on the results obtained from the current study, the upcoming research work will deal with the efficiency of the manufactured mortar used adjacent to the tufa stone in term of performance, salts tests and complementary durability tests.

\section{Acknowledgement}

The authors wish to thank the AUF (Agence Universitaire de la Francophonie) for providing a research grant for a twoweek visiting to University of Orleans - France. The authors would like to thank the technicians and members of the University of Orléans (PRISME) for the materials provided and for assistance in implementing the experimental program. The beneficial contribution of CEREMA (Centre d'études et d'expertise sur les risques, l'environnement, la mobilité et l'aménagement) during laboratory tests is also recognized. A special acknowledgement is devoted to the College of Engineering/University of Mosul for its encouragement and incorporeal support to the authors for researches publishing. The authors also would like to thank Martin Colbourne for his professional proofreading of the manuscript.

[3] Maras, M. M., Kose, M. M., Rizaoglu, T. "Microstructural Characterization and Mechanical Properties of Volcanic Tuff (Malatya, Turkey) Used as Building Stone for the Restoring Cultural Heritage", Periodica Polytechnica Civil Engineering, 65(1), pp. 309-319, 2021. https://doi.org/10.3311/PPci.16977

[4] Al-Omari, A., Khattab, S. "Characterization of Building Materials Used in the Construction of Historical Al-Omariya Mosque Minaret in Mosul's Old City, Iraq", Journal of Building Engineering, 33, Article number: 101645, 2021.

https://doi.org/10.1016/j.jobe.2020.101645 
[5] Ulukaya, S., Yoruç, A. B. H., Yüzer, N., Oktay, D. "Material Characterization of Byzantine Period Brick Masonry Walls Revealed in Istanbul (Turkey)", Periodica Polytechnica Civil Engineering, 61(2), pp. 209-215, 2017. https://doi.org/10.3311/PPci.8868

[6] Beck, K. Al-Mukhtar, M. "Formulation and Characterization of an Appropriate Lime-Based Mortar for Use with a Porous Limestone", Environmental Geology, 56, pp. 715-727, 2008. https://doi.org/10.1007/s00254-008-1299-8

[7] Al-Omari, A., Brunetaud, X., Beck, K., Al-Mukhtar, M. "Coupled Thermal-Hygric Characterisation of Elastic Behaviour for Soft and Porous Limestone", Construction and Building Materials, 62, pp. 28-37, 2014.

https://oi.org/10.1016/j.conbuildmat.2014.03.029

[8] Beck, K., Al-Mukhtar, M. "Cyclic Wetting-Drying Ageing Test and Patina Formation on Tuffeau Limestone", Environmental Earth Sciences, 71(5), pp. 2361-2372, 2014.

https://doi.org/10.1007/s12665-013-2637-z

[9] Janvier-Badosa, S., Beck, K., Brunetaud, X., Guirimand-Dufour, A., Al-Mukhtar, M. "Gypsum and Spalling Decay Mechanism of Tuffeau Limestone", Environmental Earth Sciences, 74(3), pp. 2209-2221, 2015.

https://doi.org/10.1007/s12665-015-4212-2

[10] Beck, K., Al-Mukhtar, M., Rozenbaum, O., Rautureau, M. "Characterization, Water Transfer Properties and Deterioration in Tuffeau: Building Material in the Loire valley-France", Building and Environment, 38(9), pp. 1151-1162, 2003. https://doi.org/10.1016/S0360-1323(03)00074-X

[11] Cherrak, M., Bali, A., Silhadi, K. "Concrete Mix Design Containing Calcareous Tuffs as a Partial Sand Substitution", Construction and Building Materials, 47, pp. 318-323, 2013. https://doi.org/10.1016/j.conbuildmat.2013.05.051

[12] Moropoulou, A., Bakolas, A., Bisbikou, K. "Investigation of the Technology of Historic Mortars", Journal of Cultural Heritage, 1(1), pp. $45-58,2000$. https://doi.org/10.1016/S1296-2074(99)00118-1

[13] Arandigoyen, M., Alvarez, J. I. "Pore Structure and Mechanical Properties of Cement-Lime Mortars", Cement and Concrete Research, 37(5), pp. 767-775, 2007. https://oi.org/10.1016/j.cemconres.2007.02.023

[14] Maravelaki-Kalaitzaki, P., Bakolas, A., Karatasios, I., Kilikoglou, V. "Hydraulic Lime Mortars for the Restoration of Historic Masonry in Crete", Cement and Concrete Research, 35(8), pp. 1577-1586, 2005.

https://doi.org/10.1016/j.cemconres.2004.09.001

[15] Pacheco-Torgal, F., Faria, J., Jalali, S. "Some Considerations about the Use of Lime-Cement Mortars for Building Conservation Purposes in Portugal: A Reprehensible Option or a Lesser Evil?", Construction and Building Materials, 30, pp. 488-494, 2012. https://doi.org/10.1016/j.conbuildmat.2011.12.003

[16] CEN "EN 459-1:2015 Building lime - Part 1: Definitions, specifications and conformity criteria", European Committee for Standardization, Brussels, Belgium, 2015.
[17] RILEM TC, "CPC 11.3 Absorption of water by concrete by immersion under vacuum", In: RILEM Recommendations for the Testing and Use of Constructions Materials, RILEM, Paris, France, 1984, pp. 36-37. https://doi.org/10.1617/2351580117.018

[18] CEN "LST EN 1015-11 Methods of test for mortar for masonry Part 11: Determination of flexural and compressive strength of hardened mortar", European Committee for Standardization, Brussels, Belgium, 2004.

[19] AFNOR "NF P94-420 Roches-détermination de la résistance à la compression uniaxiale" (Rocks - determination of uniaxial compressive strength), Paris, France, 2000.

[20] ASTM "D3080-11: Standard test method for direct shear test of soils under consolidated drained conditions", ASTM International, West Conshohocken, PA, USA, 2011.

[21] AFNOR "NF P94-411: "Roches-Détermination de la vitesse de propagation des ondes ultrasonores en laboratoire - Méthode par transparence" (Rocks - Determination of the speed of propagation of ultrasonic waves in the laboratory - Transparency method), Paris, France, 2002.

[22] ASTM "D5930-97 Standard test method for thermal conductivity of plastics by means of a transient line-source technique", ASTM International, West Conshohocken, PA, USA, 2001.

[23] Brouard, Y., Belayachi, N., Hoxha, D., Ranganathan, N., Méo, S. "Mechanical and Hygrothermal Behavior of Clay-Sunflower (Helianthus Annuus) and Rape Straw (Brassica Napus) Plaster BioComposites for Building Insulation", Construction and Building Materials, 161, pp. 196-207, 2018.

https://doi.org/10.1016/j.conbuildmat.2017.11.140

[24] Aalil, I., Beck, K., Brunetaud, X., Cherkaoui, K., Chaaba, A., Al-Mukhtar, M. "Deterioration Analysis of Building Calcarenite Stone in the House of Venus in the Archaeological Site of Volubilis (Morocco)", Construction and Building Materials, 125, pp. 11271141,2016 https://doi.org/10.1016/j.conbuildmat.2016.09.005

[25] CEN "EN 1925:1999 Natural stone test methods-determination of water absorption coefficient by capillarity", European Committee for Standardization, Brussels, Belgium, 1999.

[26] El-Dieb A. S., Hooton, R. D. "A High Pressure Triaxial Cell with Improved Measurement Sensitivity for Saturated Water Permeability of High Performance Concrete", Cement and Concrete Research, 24(5), pp. 854-862, 1994.

[27] Saiyouri, N., Bouasker, M., Khelidj, A. "Gas Permeability Measurement on Injected Soils with Cement Grout", Cement and Concrete Research, 38(1), pp. 95-103, 2008. https://doi.org/10.1016/j.cemconres.2007.08.015

[28] Aldaood, A., Bouasker, M., Al-Mukhtar, M. "Effect of Water During Freeze-Thaw Cycles on the Performance and Durability of LimeTreated Gypseous Soil", Cold Regions Science and Technology, 123, pp. 155-163, 2016. https://doi.org/10.1016/j.coldregions.2015.12.008

[29] Lanas, J., Bernal, J. L., Bello, M. A., Galindo, J. I. "Mechanical Properties of Natural Hydraulic Lime-Based Mortars", Cement and Concrete Research, 34(12), pp. 2191-2201, 2004. https://doi.org/10.1016/j.cemconres.2004.02.005 
[30] Lopes dos Santos, A. R., do Rosário da Silva Veiga, M., dos Santos Silva, A. M., Lopes de Brito, J. M. C. "Tensile Bond Strength of Lime-Based Mortars: The Role of the Microstructure on their Performance Assessed by a New Non-Standard Test Method", Journal of Building Engineering, 29, Article number: 101136, 2020. https://doi.org/10.1016/j.jobe.2019.101136

[31] Sala, E., Zanotti, C., Passoni, C., Marini, A. "Lightweight Natural Lime Composites for Rehabilitation of Historical Heritage", Construction and Building Materials, 125, pp. 81-93, 2016. https://doi.org/10.1016/j.conbuildmat.2016.08.033

[32] Lanas, J., Pérez Bernal, J. L., Bello, M. A., Alvarez, J. I. "Mechanical Properties of Masonry Repair Dolomitic Lime-Based Mortars", Cement and Concrete Research, 36, pp. 951-960, 2006. https://doi.org/10.1016/j.cemconres.2005.10.004

[33] Capozucca, R. "Shear Behaviour of Historic Masonry Made of Clay Bricks", The Open Construction and Building Technology Journal, 5, pp. 89-96, 2011. https://doi.org/10.2174/1874836801105010089

[34] Aalil, I., Beck K., Brunetaud, X., Badreddine, D., Cherkaoui, Kh., Chaaba, A., Al-Mukhtar M. "Restoration Mortars for the Volubilis Calcarenite Stone", Procedia Structural Integrity, 5, pp. 1123-1128, 2017. https://doi.org/10.1016/j.prostr.2017.07.106

[35] Barbero-Barrera, M. M., García-Santos, A., Neila-González, F. J. "Thermal Conductivity of Lime Mortars and Calcined Diatoms. Parameters Influencing their Performance and Comparison with the Traditional Lime and Mortars Containing Crushed Marble Used as Renders", Energy and Buildings, 76, pp. 422-428, 2014.

https://doi.org/10.1016/j.enbuild.2014.02.065
[36] Güney, B. A., Caner, E. "Thermal and Hygric Expansion Characteristics of Mortars and Bricks Used in the Dome Structures of Turkish Baths from 14th and 15th Centuries", Construction and Building Materials, 95, pp. 757-761, 2015.

https://doi.org/10.1016/j.conbuildmat.2015.07.176

[37] Maravelaki-Kalaitzaki, P. "Hydraulic Lime Mortars with Siloxane for Waterproofing Historic Masonry", Cement and Concrete Research, 37(2), pp. 283-290, 2007.

https://doi.org/10.1016/j.cemconres.2006.11.007

[38] Elert, K., Rodriguez-Navarro, C., Pardo, E. S., Hansen, E., Cazalla, O. "Lime Mortars for the Conservation of Historic Buildings", Studies in Conservation, 47(1), pp. 62-75, 2002. https://doi.org/10.2307/1506835

[39] Falchi, L., Müller, U., Fontana, P., Izzo, F. C., Zendri, E. "Influence and Effectiveness of Water-Repellent Admixtures on Pozzolana-Lime Mortars for Restoration Application", Construction and Building Materials, 49, pp. 272-280, 2013. https://doi.org/10.1016/j.conbuildmat.2013.08.030

[40] Isebaert, A., Van Parys, L., Cnudde, V. "Composition and Compatibility Requirements of Mineral Repair Mortars for Stone-A review", Construction and Building Materials, 59, pp. 39-50, 2014. https://doi.org/10.1016/j.conbuildmat.2014.02.020 